\title{
What has the beast's mark to do with the COVID-19 vaccination, and what is the role of the church and answering to the Christians?
}

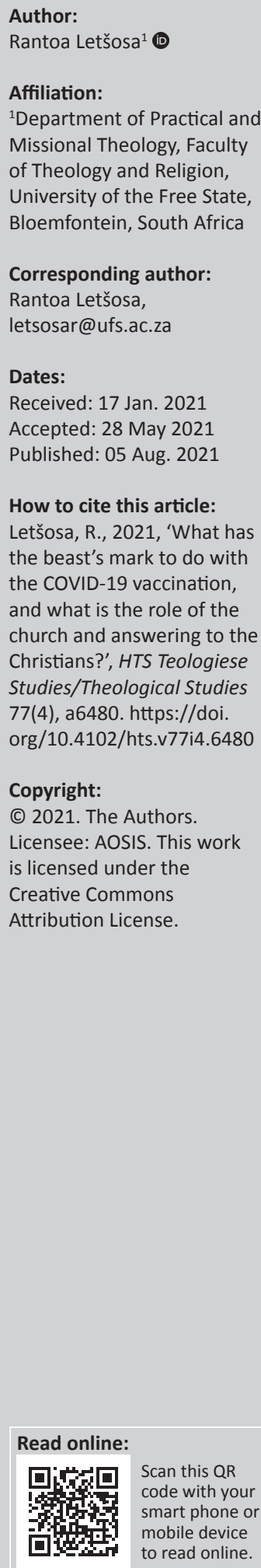

Coronavirus disease 2019 (COVID-19) escalated into a real pandemic within 3.5 months and had caused 183000 deaths in 2020. The complexities of COVID-19 since the end of 2019 and throughout 2020 left a mouth full and the second wave has not least to be said. The purpose of this article is to challenge the response of the church in a time when her voice is mostly needed. During the lockdown Level 5, churches were amongst the many trends that had to close their doors to the believers and the community. This was a great shock because churches throughout history have been known as safe havens and anchorages. Churches helped with answers to unanswered questions, and in some instances, confessional statements and creeds were born. In the case of COVID-19, a lot of conspiracy theories went viral about COVID-19 and the vaccines that were still in their research stage. Lots of speculations rose as to the cause of this pandemic. The implementation of $5 \mathrm{G}$ was viewed as the cause of the coronavirus at the beginning of 2020, and much had to be done to correct this fallacy. Another controversial fallacy was the link of the vaccination with the beast's mark, as was recently also insinuated in Chief Justice's prayer. Questions have already been asked, what is the voice of the church in this regard? Congregation deals with this in different ways. Hence the relevance to the question, how timely can exegesis be to contemporary ecclesiology? What would be relevant hermeneutics that could assist in embodying faith in a corona-defined world?

Contribution: This article strives to develop an interpretation of 666 that could be relevant to the questions asked and suggest a way forward in embodying faith in a corona-defined world and beyond.

Keywords: 666; mark of the beast; vaccination; COVID-19; Rev 13:16-18.

\section{Introduction}

John Calvin once remarked that 'the study of prophecy either finds a man crazy or it leaves him so'. While I cannot agree with Calvin completely, Revelation 13 and the theme of the mark of the beast have certainly been the occasion for wild speculation throughout the Church's history. Nevertheless, John the Apostle pronounces a blessing upon those who pay close attention to the 'words of the prophecy'. The problem has not been with the Revelation, but with the Church's hermeneutics. With a sound literal grammaticalhistorical hermeneutic, even this difficult passage can be understood. (Harless 2003:333)

The unfounded speculated theories, myths and misconceptions about a 666 infused vaccine for coronavirus disease 2019 (COVID-19) to be administered to people proliferated the media and caused a lot of fear over the last few months (IOL 2021). COVID-19 (SARS-COV-2) is a novel coronavirus that caused more than one million deaths within the very first 6 months with substantial social and economic upheavals. There is no question about the necessity of expedited pre-clinical and clinical assessments of efficacious vaccines that would curb further morbidity and mortality. However, it remains crucial what role the church as the pastoral leader, amongst other tasks, takes in sending out the right message to people and preventing unnecessary deaths that could have been prevented if the correct message has been proclaimed. This unfounded speculation around the vaccination became a very contentious issue at this stage and not only a South African problem but all over the globe where there are Christians (O'Sullivan 2020:1). The case dealt with here is more complex than complicated and needs some clear ground rules for interpretation. These speculations proliferate amongst believers from all spheres, religious, health as well as politics. They also received an endorsement in the prayer of Chief Justice Mogoeng Mogoeng who, in his prayer, surmised the possibility of a vaccine from the devil meant to infuse 666 and

Note: Special Collection: From timely exegesis to contemporary ecclesiology: Relevant hermeneutics and provocative embodiment of faith in a Corona-defined world - Festschrift for Stephan Joubert, sub-edited by Willem Oliver (University of South Africa). 
advance Satan's agenda or contain something that could corrupt the DNA of the human being (YouTube-EWN 2020). There are clamouring, conflicting voices on the whole issue of the vaccines and, as indicated before, amongst scientists and Christians. The defence of " 666 " vaccine prayer' of Chief Justice Mogoeng Mogoeng on YouTube - (YouTube - EWN 2020), recently received likes of $9.7 \mathrm{~K}$ compared to 228 dislikes. Out of the 3289 comments as of 31 December 2020, roughly 3000 support the view of such a possibility of a 666 infused vaccine (YouTube - EWN 2020).

In YouTube videos of 25 September 2021 titled 'COVID-19 vaccine' and of 29 September 2020 from India Today, where it was explained how a microchip is being used to check the effect of the drugs on COVID-19, under comments, there is still a mistrust that the microchip is what would be implanted in the human being for all its Satanic purposes, despite all clarifications on the matter (see also BBC News of 30 May 2020). In other media, Bill Gates is referred to as the beast and that all people would be carrying his mark (see Richardson [2020] in a YouTube video of 03 May 2020 and ApologiaStudios YouTube video of 18 April 2020). In this article, it will become evident how history repeats itself as this was the case with Hitler (Elise \& Zhang 2020:3). A recent article published in principia-scientific.com shows Bill Gates admitting the COVID vaccine to change the DNA, and as a result, doctors are rebelling (O'Sullivan 2020:1). So, the question is, in this media war - where there are many opposing voices and interpretations around the vaccine, should the church just be silent, and if she speaks, what message should be given? What role do exegesis and hermeneutics play within this context, and is God silent on what is happening? This article endeavours to respond to this question through an exegetical study of Revelations 13:16-18 and a hermeneutical approach and come up with relevant questions that could help the church find appropriate answers for a COVID-19-defined world. In this approach, a study on the text and the shaping of Revelations 13 will be done to assist with the location.

\section{The Text of Revelations 13}

Harless (2003:337) pointed out that the only textual issue to be concerned with is the correct reading of Revelation 13:18, кal o

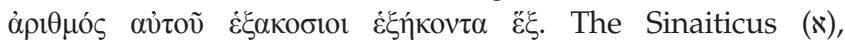
Alexandrinus (A), Chester Beatty papyrus $\left(\mathrm{p}^{47}\right)$, many Italic manuscripts (it), the Vulgate (Vg) and most other manuscripts, including the Syrian (syr) and Coptic (cop) have this reading. In contrast, the Italic manuscript (it) has $\tau \varepsilon \sigma \sigma \varepsilon \rho \alpha \kappa o v \tau \alpha$, instead of $\dot{\varepsilon} \xi \eta \dot{\eta} \kappa \nu \tau \alpha$, which could probably be because of a scribal error confusing Revelation 14:1 with 13:18. However, as Harless (2013:337) reasons, this reading does not appear until the ninth century. The $\delta \varepsilon \kappa \alpha$ of Ephraemi Rescriptus (ca. fifth century) and the Italic manuscript Harleianus Londiniensis (it ${ }^{2}$, eighth century) also gives reason for concern and hence Irenaeus roundly condemned it as misleading and for this reason, Irenaeus' testimony and the late nature of the variant reading lend confidence that 666 , not 646 or 616 , is the correct reading. A few witnesses, including one notably early manuscript, record the number as 616 (Brannan \& Loken 2014).
This information highlights the fact that Revelations 13 has always been a challenging text and is open to misunderstanding. It has always been a struggle to find the correct reading and this article will guide on how to deal with the interpretation in relation to the COVID-19 vaccination.

\section{The shaping of chapter 13}

Beale (1999:583) reasons that about two-thirds of all the OT references in Revelation 13 come from Daniel. John heavily draws from Daniel in describing the church's situation in the world of his day because he, like Daniel, had to fight the status quo of apostasy, compromise and syncretism. The Christians in Asia Minor faced a world system that was a Satanic parody of God's ordering of the world, characterised by the blasphemy of rulers who claimed deity and by the apostasy of so-called Christians who acquiesce to the compromising demands of emperor worship and of the institutions of pagan society (see on 2:9, 14, 20-21).

Beale (1999:729) also states that the supporters of the pagan society forsook the holy covenant (Dn 11:30) and were hypocrites (Dn 11:34b) who gave allegiance to the selfdeifying and deceiving king prophesied by Daniel (cf. Dn 7:25 LXX, Dn 8:23-25; 11:30-39; 12:4 LXX). Daniel also prophesied that deception would come not only from outside the covenant community or the church but also from within (Dn 11:32) where the Jewish apostates instead of the evil king were those who 'seduced' the faithful (cf. likewise Rv 2:9, 17, 20-21; 3:9). Those with wisdom and understanding can see through the deceptors, remain faithful to the Lamb and not follow the beast like Daniel's maskilim (wise men). Therefore, it is not surprising that John views the apostasy, deception and persecution prophesied by Daniel as beginning to occur in his own day and thus warns Christ's followers to read the times. It is noteworthy that Beale (1999:730) highlights that it is crucial to understand that it is ultimately God who sends the beasts of deception to test the genuineness of faith of those who believe in him. The shaping of Revelations 13 clearly shows that all the challenges we are faced with are not a new phenomenon. Satan throughout history tried to imitate God and deceive many people. It is not always to keep focused on the Lamb in times of trial and many become easily deceived. Great understanding and interpretation of the times are needed.

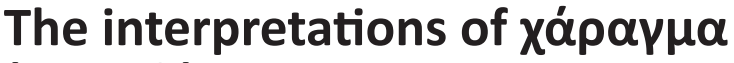 (a mark) \\ Revelation 13:16-18}

Verse 18 of Revelation 13 is one of the most debated verses in the entire book because of widespread disagreement over the identification and meaning of the number 666. It will be shown that the interpretation of Revelation 13:16-18 is not as straightforward and there is no straightforward answer. Instead, the hermeneutics behind this issue is very complexdifferent perspectives come into play as shall be discussed 
in this article. The exact meaning behind the 'mark of the beast' is difficult to fully understand in its historical context (Stadel 2016). Traces of the notions of a mark are already found in Isaiah 44:5 (the mark of belonging to the Lord on the right hand) and Ezekiel 9:3-11 (mark on the forehead of all those who moan and groan over all the abomination practised in the city of Jerusalem). In Psalms of Solomon 15:6-9, the mark of the believer (indicating salvation) is contrasted to the unbeliever's mark (indicating destruction).

Stadel (2016) gave four common interpretations of $\chi \alpha ́ \rho \alpha \gamma \mu \alpha$. Firstly, $\chi \alpha \alpha \alpha \gamma \mu \alpha$ could refer to insubordinate slaves and captured soldiers being tattooed on the arm with either an owl, a galloping horse or an ivy leaf, or inscribed with their new master's seal. Secondly, it could refer to an imperial seal with the image and name of a Roman emperor, implying technical legal understanding of the word. Thirdly, reference could be to the Roman coin, with an image of a Roman emperor, for both private and public commerce and fourthly, it could refer to the Jewish practice of wearing phylacteries. Stadel (2016) concluded that these interpretations are of no help to understand the meaning of Revelation 13:16 because of the following reasons. $\chi \alpha$ ó $\alpha \gamma \mu \alpha$ for subordination was more of a disgrace than a sign of loyalty. The imperial seals used were meant for specialised imperial records and not for public or commercial usage. Moreover, the mark in Revelation 13:16 is on the person's right hand or forehead and not on a coin; and Jewish phylactery was typically worn on the left arm rather than the right (see Ex 13:9 and Dt 6:8).

Harless (2003:347-351) had five common interpretations of the mark. Amongst the four mentioned by Stadel (2016), he separated the tattoo or branding by the soldiers with the name of their general, showing devotion to him as a matter of choice. Unlike Stadel, Harless saw a significance in all five common interpretations of the mark. The mark for the slave, if connected with the mark of the beast, could indicate that those who worship the beast are his property. According to Osborne (2002:517), there are arguments that this indication of ownership could be a parody of baptism depending on the identification of the seal in 7:1-8 as baptism. It is possible that it is a satanic counterpart of the sealing of those belonging to God in this context wherein Satan is deliberately copying God. $\chi \alpha$ ó $\alpha \gamma \mu \alpha$ of the soldiers, if connected with 666, could indicate that those worshipping the beast are also devoted followers. In the case of the contract of buying and selling, $\chi \alpha$ ó $\alpha \gamma \mu \alpha$ with the name of the emperor if connected with 666 could indicate acceptance of the authority of the beast. The inscription of the emperor's name on the coin, if connected with 666, could refer to being property of the beast, and lastly, the receiving of a certificate because of the burning of a pinch of incense to Caesar if connected with the 666 could mean that the $\chi \alpha \rho \alpha \gamma \mu \alpha$ of the beast may be the certificate of worship, which Christians could only receive at the cost of denying their faith. According to Barry et al. (2016), 'right hand or on their forehead' may be a parody of the seal that Christians had (Rv 7:3;14:1) or of the Israelites' bearing God's law. Jews often wore boxes (called phylacteries) containing portions of the Law on their foreheads or hands.
Osborne (2002:518) noted that in 3 Maccabees 2:28-29, the Ptolemaic king Philopater I (217 в.с.) forced Egyptian Jews to be registered in a census and then branded with the ivy leaf sign of Dionysus. The mark signified both the rejection of former loyalties and the absolute acceptance of a new allegiance. Refusing the $\chi \alpha \dot{\alpha} \rho \gamma \mu \alpha$ led to execution. The resulting polarity is that believers are stamped with the 'seal' of Christ (Rv 7:3-4; 22:4), whilst unbelievers have the 'mark' of the beast (13:16-17). There are no neutralities in this war; not to belong to Christ is to belong to the beast.

Osborne (2002:518) was of the opinion that the Roman government persecuted but did not use economic sanctions against Christians. Hence, this could possibly have been the result of local persecutions. The letters to Smyrna and Philadelphia present the Christians as poverty-stricken (2:9) and of 'little strength' (3:8) because of Jewish opposition. The situation of Pergamum and Thyatira differed; the guild structure controlling the life of the city placed enormous economic pressure on believers to conform to the pagan mores. It is worth noting that the notion of marking people was not unfamiliar to the first readers. It would thus not be surprising for people to read the vaccination as a mark of the beast meant to derail people from following the Lamb in as much as this is a great fallacy.

\section{The parody of Revelation 13:11-18}

Verse 11, then I saw another monster - this is now the second monster, after the dragon. Verse 12, the first monster had a fatal wound that had been healed, verse 13 the wound was a swordwound, but now this monster is alive. In this, we see a parody of the Son who has died and was resurrected. Revelations 15:2 (cf. 20:4) clearly showed that the number is that of the first beast, described in 13:1-8 and not of the second beast, described in verses 11-16. Wright (2011:120) viewed what is happening in this pericope as an unholy trinity, a parody of the Trinity. Interpretations of the number have fallen into three general categories. (1) From the time of the Roman Empire until the present, there have been many attempts to calculate by gematria the number of various world leaders and identify them as the beast. (2) The number is also taken as chronological and as indicating the duration of the beast's reign, whether it be the heathen state, Islam, the Papacy or some other entity. (3) The number is taken as symbolic for the Antichrist, for antichristian power or both (Beale 1999:586). And now quite interesting is the new suggestion that the number could refer to the COVID-19 vaccination (:974).

\section{Activities that the second beast is engaged in}

Mangum (ed. 2020) highlighted seven activities. There is an exciting movement from aorist tenses in 13:1-8 to imperfects in 13:11 to present tenses in 13:12-18, undoubtedly for more extraordinary vividness in describing the ongoing work of the Antichrist and his false prophet. The verb $\pi$ oté $\omega$ occurs nine times in verses 12-16. As a main verb, it emphasises the implausible activity of the false prophet 
on behalf of his master. The dragon gives his authority to the first beast (13:2b) and that beast gives his authority to the second. This ' $\bar{\varepsilon} \xi o v \sigma i \alpha \nu \ldots \pi \tilde{\alpha} \sigma \alpha v^{\prime}$ (v. 12) refers to the complete transfer of authority from the Antichrist to his

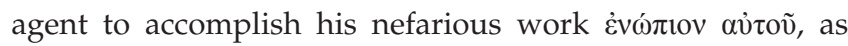
his commissioning, and under his authority.

13:12 The second beast engages in seven activities. Firstly, he exercises the authority of the first beast. Secondly, he causes the earth to worship the first beast.

13:13 Thirdly, he caused the earth and all inhabitants to worship the first beast.

13:14 Fourthly, the beast deceives humankind utilising his miraculous signs. He tells them specifically to make a statue of the first beast.

Osborne (2002:513) stated that the performing of $\sigma \eta \mu \varepsilon i \tilde{\alpha}$ $\mu \varepsilon \gamma \alpha \dot{\lambda} \alpha$ was a significant focus of his 'work', which is the third $\pi$ oเعi in the passage. This was the counterfeit miracles mirroring those performed by Elijah and Christ as well as the two witnesses of 11:5-6. Exodus 4:17; 7:9-10; 10:1-2 described Moses as a prophet who performed miraculous signs, and Elijah and Elisha are also counted amongst those who produced spectacular miracles. The Gospel, according to John, is built around Jesus' $\sigma \eta \mu \varepsilon i ̃ v$, which provided a theological pointer to the significance of Jesus as the Christ.

Counterfeit miracles, signs and wonders typify false teachers and prophets throughout history (Dt 13:1-4 and 2 Th 2:9). In particular, the false prophet parodies Elijah, who called down fire from heaven both at Mount Carmel (1 Ki 18:36-39) and with the soldiers sent to arrest him (2 Ki 1:10-14). Like Elijah, the false prophet calls down fire from heaven $\dot{\varepsilon} v \omega \dot{\pi} t o v$ $\tau \tilde{\omega} v \alpha \dot{\alpha} v \theta \rho \omega ́ \pi \omega v$. Osborne (2002:514) does not see this to be a religious act but rather a public-relations performance intended to promote allegiance to the false trinity. The use of prophetic power by the false witness is for selfaggrandisement, to be seen and worshiped by the people (e.g. Jr 23:9-14; Ezk 13:1-23).

13:15 Fifthly, he animates the image of the beast that earth dwellers make so that it can even speak and destroy those who refuse to worship it.

13:16-17 Sixthly, he causes the whole world to take the mark $(\chi \alpha \dot{\alpha} \alpha \gamma \mu \alpha)$ of the beast; then (seventh) he makes business transactions impossible for those who do not possess the mark of the beast. According to Osborne (2002:517), the receiving of the $\chi \alpha \dot{\alpha} \rho \gamma \mu \alpha$ was to identify their allegiance to the Antichrist. The emphasis is on $\pi \alpha \dot{v} \tau \alpha \varsigma$, meaning every human being, unbeliever and believer. Every subgroup of humanity is pointed out with the article's repetition before each to stress the individual groups. The three pairs of social categories emphasised are the small and the great, the rich and the poor, the free and the slave. In all the occurrences in Revelations, the indication is clear that God does not play favourites and that there is no distinction between the haves and the have-nots before God or the satanic realm. Osborne (2002:513 argued that this pericope points to the false trinity's pretension that the beast is the Christ. The beast's mark that the second beast causes the whole world to receive is the number of a human being. It adds up to 666 . The revelation of this number prior to the appearance of the beast sensitises humankind to its significance; in revealing it ahead of time, God imparts wisdom to those who will heed his revelation to reject the mark.

\section{Past identifications employing Gematria}

According to Beale (1999:717), using alphabet letters for numerals in the language of the ancient world was not a strange phenomenon. The first nine letters of the Greek alphabet represented the numbers one through nine $(\alpha=1$, $\beta=2$ and so forth). Gematria was used to represent words and names by the sums of their numerical equivalents. In Sib. Or. 1.325, Jesus is represented by the number 888 ( $\mathrm{I}=10$, $\mathrm{H}=8, \Sigma=200, \mathrm{O}=70, \mathrm{Y}=400, \Sigma=200$ ), which symbolised beyond perfection.

Beale (1999:718) furthers stated that although the number 666 has been identified by many with Nero, this cannot be calculated in Greek, but with a transliteration of the Greek Nerōn Kaisar into Hebrew, one may come up with 666 (nun = 50 , resh $=200$, waw $=6$, nun $=50$, qoph $=100$, samech $=60$, resh = 200). The calculation is based on the defective Hebrew spelling of $q s r$ without a yodh after the qoph, a spelling that some argue is attested in one of the Judean scrolls and in the Talmud. A connection with Nero could be pointed to by the fact that early authors, in both apocalyptic and secular circles, referred to Nero as a 'beast', and the calculation of the Hebrew word for 'beast' is 666 . It is believed by some that the textual tradition with 616 (C) was an intentional change under the influence from the Latin form of the name Nero, which, transcribed into Hebrew characters (nrô qsr), produces 616. Harless (2003:352) had a different opinion that 666 was not the gematria used for Nero; 1005 was. He indicated no direct evidence that the Nero redivivus myth is intended and called this view a fanciful interpretation. An allusion to Nero redivivus may be intended but the myth itself is not endorsed. MacArthur (2006:73) also disagreed with a Nero identification and testifies that this text reveals very little about the meaning of 666. It is unwise to speculate beyond what is said.

Wright (2011:122) supported the Nero identification and mentions that the number 666 is not just a cryptogram but also a parody. The number of perfection for John would most probably be 777 . Nero, and the system he represented and embodied, was but a mockery of the real thing, one short of the right number three times over. Jesus is the reality, and Nero, just a dangerous, blasphemous copy. He further argued that one should not only recognise this but also search our consciences and our own societies and enquire to what extent we, too, have been deceived by fakes posing as the real thing. 
Even though the identification of the 666 with Nero is convincing to many scholars like Wright, Beale (1999:719) identified five reasons why this could not be the case, in addition to what has already been mentioned: (1) The Nero identification would suppose John's audience who were native Greek readers to be knowledgeable with the Hebrew language and its system of gematria. It is accepted that some were Jewish Hellenistic Christians. (2) For the Nero view, it is questionable why they would have chosen 'Caesar Nero' because Nero had many other names and titles. (3) In transliterating a foreign name into Hebrew, there is considerable latitude in putting in or leaving out or varying vowel letters. There are three possible alternative equivalents for the $\Sigma$. And why would John not use a Greek form instead of a Hebrew form? (4) A Nero identification was unknown to the earliest church fathers. Harless (2003:353), refuting the Nero identification, argued that if Irenaeus, a disciple of Polycarp (ca. AD 69-155), who studied under the Apostle John, did not know the answer, it is probably because the answer was not yet revealed. (5) John calls for moral discernment and not for intellectual, mathematical prowess in his exhortation that his readers 'have a mind to calculate'. Beale (1999:720) also mentioned that another solution that is not recommended adds up the numerical value of the initials of the emperors' names from Julius to Vespasian, which comes to $666\left(\mathrm{~K}\left[{ }^{\prime}{ }^{C}\right.\right.$ Caesar'] $=20, \Sigma=200, \mathrm{~T}=300, \Gamma=3, \mathrm{~K}=20$, $\mathrm{N}=50, \Gamma=3, \mathrm{O}=70$ ). This same method is used to list emperors beginning with Julius Caesar and the problem with this method unjustifiably includes some and excludes other emperors.

Beale (1999:720), out of interest, also mentioned other names identified with 666 - Teitan (Titus?) and Lateinos, which could be synonyms for the Roman Empire. In this century, the names of the German Kaiser and Hitler have also been calculated to equal 666. Beale (1999:720) also indicated that Hebrew transliteration of Greek ho Nikolaites ('the Nicolaitans', 2:6, 15) yields 666; when 666 is written in Hebrew letters, it spells a word meaning 'you should destroy' and that the info on Roman coins summarising Vespasian's legend yields 666 .

In agreement with Beale (1999:721), all attempts to identify 666 with the literal calculation of some individual's name encounter difficulty. There are also beliefs that 666 is one of John's regular figurative use of numbers (cf. Rv 5:11; 7:4, 9; $9: 15 ; 20: 8$ ), which were never intended to be calculated (Luter 2017:2035). None of the many proposed solutions using gematria is ultimately satisfactory because there are so many names, ancient and modern, that come to 666, and moreover, it is easy to turn a name into a number but hard to deduce the right name from a number. Salmon (1904) (more than a century ago) formulated three 'rules' that commentators have used for making any desired name equal 666:

First if the proper name by itself will not yield it, add a title; secondly, if the sum cannot be found in Greek, try Hebrew, or even Latin; thirdly, do not be too particular about the spelling.... We cannot infer much from the fact that a key fits the lock if it is a lock which in almost any key will turn. (p. 230)
A literal calculation method can hardly yield the right interpretation. All the numbers in Revelations seem to have figurative significance and would therefore symbolise some spiritual reality. It is improbable that John intended any kind of literal gematria calculation. The immediately following vision of 144000 saints with Christ's and God's names 'written on their foreheads' (14:1) would attest to this argument. The contrast intended is between the beast's name and the Lord's name. If the latter vision symbolises a purely spiritual reality, which it does, then so does the former. This is also true of the beast's number as it is synonymous with his name. Easley (1998:234) stated that the trouble with mathematically identifying this is that an infinite number of additional problems may be answered by the sum ' 666 ' and calls this a riddle of biblical proportions.

A Nero identification is refuted by many scholars; even the early church fathers were not aware of such. It is also evident that all attempts to identify 666 through gematria do not lead to satisfactory answers. Turning names into numbers is a more straightforward exercise than deducing the right names from numbers. Attempts have also been made to link the beast's mark even with technology and now with a vaccine because of the unprecedented growth of the pandemic and the fear that accompanies it. Moreover, one of the unfortunate results of unbridled use of gematria was that it often trivialised Scripture and reduced biblical interpretation to an esoteric and silly use of math (Easley 1998:234).

Osborne (2002:521), in a detailed argument around the number and meaning, concluded that the best option is 'Nero Caesar', although it is no more than a tantalising possibility. However, in support of Harless, he also reasons that should the identification with Nero be adopted, it would not mean that John believed the Nero redivivus legend and expected Nero to return shortly. Sproul (ed. 2015:2321) shares the same sentiments and holds that by the time of Domitian, the earlier Emperor Nero had become a traditional antichrist figure, and 666 was probably already known to be the numerical value associated with the name Nero Caesar in Hebrew - a different opinion from those arguing that a Nero identification was unknown during this time. From these arguments, both Osborne and Sproul are of the opinion that the coming Antichrist for John would be a Nero-like figure. The use of 666 as the threefold counterpart to the completeness of seven and the absolute perfection of 'Jesus' as 888 could well also be intended. Osborne (2006:521) warns that in the final analysis, we must remain uncertain regarding the actual meaning of 666. The above discussion is as far as we can go; only first-century readers would have known whom the beast was referring to in their lifetime, though it is hard to say how much they knew. This could most probably have been linked to the oppressive Roman Empire (Barry et al. 2016).

In the Bible, the number three signifies completeness, as, for example, in the completeness of the Godhead in Revelation 1:4-5, which is parodied by the dragon, the beast and the false prophet here in ch. 13 (and in 16:13). Therefore, 
six repeated three times indicates the completeness of sinful incompleteness found in the beast. The beast epitomises imperfection whilst appearing to achieve divine perfection (Beale 1999:722). Therefore, during John's time, the provincial councils made up of political representatives from the major towns and priests of the imperial cult were probably included in these ruling bodies as the second beast's primary expression, Rome exercised its local rule through them. The foreign beast from the sea ruled through these indigenous, local authorities who corporately were part of the second beast (Beale 1999). Already from this explanation, it would be very unlikely that the mark of the beast would have referred to some vaccination that would come through a pandemic (717).

\section{Contextualisation of the beast}

The intention with the previous section debated on the issues surrounding the identification through gematria. Biblical scholars have discussed at length the hermeneutics behind 666 without a general consensus, and innumerable explanations have been given of the cryptogram. It was also presented in the previous section that the 1st-century cryptic (Hebrew) reference to Nero receives a considerable support (see eds. Cross \& Livingstone 2005:1174-1175). Hence, this section will have a look into a contextual interpretation.

Elwell and Beitzel (1988:861) had the notion that one should see the second beast within a context of preliminary fulfilment, appealing to Christians to recognise the true nature of the godless Nero as having the antichrist's character therefore have to refuse allegiance to him. They also suggest that this identity with the mark could be an expression of one's allegiance to the antichrist as expressed in the cult of emperor worship, and therefore this activity of worship and not a literal number on one's body could be intended.

In line with Elwell and Beitzel (1988:861), it is assumpted that there are also clear arguments that it was not the intention of John to make his readers solve this mystery through the use of gematria and that if that was the case, he would have added (in Greek or Hebrew) to guide his audience as he would in other texts in Revelations. The text should rather be seen as a parody of the Trinity and be understood spiritually.

The two beasts that John saw symbolised different categories of leadership. The one from the sea (13:1-10) symbolised the Antichrist with political power over the earth's inhabitants. The second beast is from the earth (vv. 11-18) and represented the Antichrist's assistant, which is the religious leadership dedicated to securing universal worship of the Antichrist (Elwell \& Comfort 2001:1404). These two authors also believed that the beast is understood to be sent by God to test the faith of the human being.

For Wright (2011:121), it is unlikely that John is cryptically identifying an emperor to avoid persecution in case his work falls into the hands of Roman officials. He is already in exile and not afraid of further suffering. He is also not attempting to save his readers from persecution. His mission is rather to help them to remain faithful witnesses, even to the point of death. Wright (2011:121) further opined that followers of Christ faced a Catch-22 back then. They also had the challenge of choosing between reality and what appears to be a parody. As there was no clear-cut for them, we also sit with the same dilemma. The Bible does not always give us straightforward responses on life questions and challenges. We prayerfully have to make right decisions and usually that can be misunderstood or misinterpreted by fellow Christians.

For Price (1984:196), what is depicted by the execution of believers for refusing to worship the beast is the establishment of the provincial cult of Domitian at Ephesus, with its colossal statue. This fits the known geographical and temporal contexts as this event at Ephesus involved the whole province's participation. Price (1984:198) further attested that such a large-scale involvement by the entire province led to extreme pressure on Christians to conform. The second beast is generally identified, with the first, as the Roman state (see on v 11). But it is not identical to the Roman state. Vv 11-17 showed that the beast includes the political, religious and economic institutions of Roman culture, including the culture of Asia Minor, all of which were connected with emperor worship. Even the trade guilds' patron deities were worshiped in association with the imperial cult (see on 2:9-21). There were, therefore, few facets of society from which Christians could escape pressures to idolatry. Indeed, the state was inextricably linked to the religious, economic and social facets of culture. Wright (2011:120) viewed the second beast as the local elites with horns like those of a lamb - whilst in reality, they are far from being lambs.

What also comes into play is that the mark of the beast 666 appears to be a parody of the mark of the Lamb (Rv 14:1), which protected those with the mark from the coming wrath of God (see also $\operatorname{Rv}$ 7:3 and 9:40). It remains a deliberate choice to accept or reject the mark - there is no room for neutrality, and there are consequences either way. A few activities of the second beast have been identified within a specific order, and it is essential to ask if that order plays any significant role in determining the beast and whether the mark will be the last performance as in the text or the first. The suspicion of the possible invention of a new world order would be determined by order of the activities of the beast. It is unlikely that the second beast will deceive people into taking the mark and only afterwards deceive them into worshipping the first beast according to the pericope. It was not the intention of the article to discuss anything concerning the possibility of changing the DNA; however, there are social media interpretations that the change in DNA will make Christians backslide and lose their faith in their Lord (Bohlinger 2020).

Elwell and Comfort (2001:861) viewed 'the mark of the beast' or 666 , as relating to the identity of the followers of the Antichrist. Believers are warned to remain steadfast and faithful to the Lamb and to own his name upon their foreheads. They need to pray for discernment to distinguish 
the reality from the parody and to act accordingly. It is impossible for those whom the Lamb has died for to receive the mark of the beast.

\section{The 666 and the vaccination}

It is not a strange phenomenon for disbelief to exist with regard to vaccination. This could be for various reasons, amongst which are vaccine efficacy, the adverse effects of vaccination, recommendations of healthcare professionals, knowledge, social influences, information about the vaccine, perception of not being at risk, and general opposition against vaccines (Dizbay \& Öztürkoğlu 2021:4). It can also be mentioned that part of the interpretation of the spiritual effect of the vaccines has to do with a specific cultural determined worldview. The main concern is that apathy towards vaccines could have a significant impact on the immunisation strategy and result in more deaths.

Kabra and Singh (2021) argued that there are various vaccination strategies in existence and amongst which whole virus vaccine, subunit vaccine, and nucleic acid vaccines are in the pipeline. They also opine that multinational companies like Johnson and Johnson, along with research organisations in many nations, took the initiative and that there are also various other strategies based on inducing neutralising antibodies against surface-exposed spike (S) glycoprotein or $S$ protein. Moreover, there are also multiple companies based on biotech research making use of advanced nucleic acidbased vaccine platform for COVID-19. Hence, many vaccines with different strategies involved are in preparation. These have to go through a cumbersome process of phase trials. Manufacturing and testing the toxicity also play a crucial role in this regard. These still have to be approved first by regulatory bodies. Another factor is the production of bulk that could spike the supply to meet the population's need.

From the inferences and the points put forward on the vaccines, it is unlikely that one could link the vaccines with the beast's mark. As there are many vaccines produced annually, the question remains why only this specific one would carry mysterious and ominous power. A lot of research is being done and vaccines are not produced and manufactured, and even approved overnight. To get the long-term results on the effects of the vaccine will still take time. Hence, people would have some fear on the speed with which the vaccines are produced and the unfounded speculations created around the vaccines. It is also understandable that in instances where drastic changes with an impact on humanity occur around the globe, like the introduction of credit cards, people would become suspicious of the intension behind these inventions. It is thus not surprising that the mark of the beast has already been linked with a lot of people and inventions, and meanwhile, we are still waiting for the second coming.

Kistemaker and Hendriksen (2001:393) reasoned that the second beast not only executes those who decline to worship the image of the first beast, but he also forces all categories of people to receive a distinguishing mark that sets them apart from Christians. The implication here is that Christians will not receive the mark of the beast, but only those who are not. Revelation 14:1 states that they will stand as victors on Mount Zion with the name of the Lamb and the Father. The church should take comfort in the words of the Lord in Acts 1:7 that it is not for us to know the times that the Father has set by his own authority. Yet, the church cannot remain despondent and wait hopelessly. But with the power of the Holy Spirit, the church has a mission to witness.

We all have to take hands in coming up with resolutions and help people make the right choices based on facts and not speculations. The church also has a role to play in comforting people and help them focus on the security of the mark of the Lamb that will be received by all those who overcome. It is not the church's duty to fight the coming of the second beast but rather to remain steadfast in the faith. Hence, the church has a more important role of preaching hope in a COVID-19 defined world and not fear.

Preaching and propagating conspiracy theories, building mistrust and discrediting scientists and science, in general, are not the work of the church. The church has been too gullible over the years and without scientific verification of facts has been deceived and misled. We must remember that God and science are not opposed to each other. Science is part of God's general revelation which in detail implies that man as steward must rule over creation. The church also has its own scientists, medical practitioners, engineers, specialists, etc., whom we should also listen to as instruments in the hands of the Lord. This certainly includes that what scientists can do to stem this life-destroying pandemic should be seen as good stewardship over creation.

\section{Conclusion}

In its original context, the number probably served as a warning to the (first) readers not to succumb to the pressure of the Roman Empire, who is depicted in writing as trying to take over the position of God and the Lamb. To appropriate it in our context as referring to vaccines which obviously do not have any link to such powers or such notions, but instead represent excellent research and attempts to benefit all of humankind in fighting a terrible disease killing both believers and unbelievers is an extremely irresponsible way to use the authority that the Bible has for millions of Christians all over the world. Science may bring honour to God irrespective of the belief system of scientists involved. We cannot generalise. It is also not our duty to discredit all the efforts done. The church may rather view the pandemic as an once-in-a-lifetime opportunity and challenge to grow and to regain all the ground that she has lost during the past decades or even centuries.

The intention of this article was not to encourage people to take or not to take the vaccine but to give perspective on what the Bible teaches concerning the mark of the beast/ 666 and help the church make responsible decisions. And 
perhaps one can conclude with the words of Easley (1998) regarding 666:

It is best for us to confess ignorance. Although John expected anyone with insight to calculate this number, the last nineteen centuries of preaching and teaching have kept this a secret. Surely, it is better for us to see how this entire chapter contrasts God's eternal truth with the final mockery of God's truth in which Satan will deceive the world. (p. 235)

\section{Acknowledgements Competing interests}

The author declares that they have no financial or personal relationships that may have inappropriately influenced them in writing this article.

\section{Author's contributions}

R.L. is the sole author of this article.

\section{Ethical considerations}

This article followed all ethical standards for research without direct contact with human or animal subjects.

\section{Funding information}

This research received no specific grant from any funding agency in the public, commercial or not-for-profit sectors.

\section{Data availability}

Data sharing is not applicable to this article as no new data were created or analysed in this study.

\section{Disclaimer}

The views and opinions expressed in this article are those of the author and do not necessarily reflect the official policy or position of any affiliated agency of the author.

\section{References}

ApologiaStudios, 2020, Bill Gates \& the Mark of the Beast?, viewed 15 May 2021, from https://www.youtube.com/watch?v=vCowyAPvGaA.

Barry, J.D., Mangum, D., Brown, D.R. \& Heiser, M.S., 2016, Faithlife study Bible, Lexham Press, Bellingham, WA.

BBC News, 2020, Coronavirus: Bill Gates 'microchip' conspiracy theory and other vaccine claims fact-checked, viewed 15 May 2021, from https://www.bbc.com/ news/52847648.

Beale, G.K., 1999, The book of Revelation: A commentary on the Greek text, W.B. Eerdmans, Grand Rapids, MI.
Bohlinger, T., 2020, The Covid vaccine has 666 written all over it... and why that doesn't matter according to Revelations, viewed 14 April 2021, from https://academic. matter according to Revelations, viewed 14 April 2021, from https://academic. logos.com/the-covid-vaccine-has-
matter-according-to-revelation.

Brannan, R. \& Loken, I., 2014. The Lexham textual notes on the Bible, Lexham Press, Bellingham, WA.

Cross, F.L. \& Livingstone, E.A. (eds.), 2005, The Oxford dictionary of the Christian church, University Press, Oxford.

Dizbay, I.E. \& Öztürkoğlu, Ö., 2021, 'Determining significant factors affecting vaccine demand and factor relationships using fuzzy DEMATEL method', in Advances in intelligent systems and computing, vol. 1197 AISC, pp. 682-689, Yasar University, Bornova, Izmir.

Easley, K.H., 1998, Revelation, Broadman \& Holman Publishers, Nashville, TN.

Elwell, W.A. \& Beitzel, B.J., 1988, 'Mark of the Beast', in A.E. Walter, P.C. Craigie, J.D. Douglas, R. Guelich, R.K. Harrison \& T.E. McComiskey (eds.), Baker encyclopedia of the Bible, vol. 2, p. 1405, Baker Book House, Grand Rapids, MI.

Elwell, W.A. \& Comfort, P.W., 2001. Tyndale Bible dictionary, Tyndale House Publishers, Wheaton, IL.

eNCA, 2020, Chief Justice Mogoeng defends controversial prayer, viewed 14 Apri 2021, from https://www.youtube.com/watch?v=tL2BOGgeUIE.

EWN, 2020, 5G networks: Are there health risks?, viewed 14 April 2021, from https:// ewn.co.za/2020/09/29/5g-networks-are-there-health-risks.

Harless, H., 2003, '666: The beast and his mark in Revelation', Conservative Theological Journal 7(22), 333

IndiaToday, 2020, Fact check: Do not believe this hoax about microchip implant in coronavirus vaccine, viewed 15 May 2021, from https://www.indiatoday.in/factcheck/story/fact-check-do-not-believe-this-hoax-about-microchip-implant-incoronavirus-vaccine-1726551-2020-09-29.

IOL, 2021, Chief Justice reported to judicial commission for his prayer about vaccine, viewed 30 January, from https://www.iol.co.za/the-star/news/chief-justicereported-to-judicial-commission-for-his-prayer-about-vaccine-c57458c1-fac44dfe-a3ac-3f2e51dc0d74.

Kabra, R. \& Singh, S. 2021, 'Evolutionary artificial intelligence based peptide discoveries for effective Covid-19 therapeutics', Biochimica et Biophysica Acta (BBA) - Molecular Basis of Disease 1867(1), 165978. https://doi.org/10.1016/j. bbadis.2020.165978

Kistemaker, S.J. \& Hendriksen, W., 2001, Exposition of the Book of Revelation, Baker Book House, Grand Rapids, MI.

Luter, A.B., 2017, 'Revelation', in E.A. Blum \& T. Wax (eds.), CSB study Bible: Notes, p. 2035, Holman Bible Publishers, Nashville, TN.

MacArthur, J.F., Jr., 2006, The MacArthur study Bible: New American Standard Bible, Thomas Nelson Publishers, Nashville, TN.

Mangum, D. (ed), 2020, Lexham Context Commentary: New Testament, Lexham Press, Bellingham, WA.

News24Video, 2020, God must destroy Covid-19 vaccines - Mogoeng defends his controversial prayer, viewed 14 April 2021, from https://www.youtube.com/ watch?v=zoWkUurfU6M.

Osborne, G.R., 2002, Revelation, Baker Academic, Grand Rapids, MI.

O'Sullivan, J., 2020, Bill Gates admits Covid 19 vaccine changes DNA, now doctors rebel!, viewed 14 April 2021, from https://principia-scientific.com/bill-gatesadmits-covid-vaccine-changes-dna-now-doctors-rebel.

Price, S.R.F., 1984, Rituals and power: The Roman Imperial Cult in Asia Minor, Cambridge University, Cambridge.

Richardson, J., 2020, Mark of the Beast: Bill Gates, Fauci, Vaccines, ID2020 (666 Mark of the beast here?) Underground 134, viewed 15 May 2021, from https://www. youtube.com/watch?v=s9CHC1gRNIA.

Salmon, G., 1904, An historical introduction to the study of the books of the New Testament, Murray, London.

Sproul, R.C. (ed.), 2015, The reformation study Bible: English Standard Version, 2015 edn., Reformation Trust, Orlando, FL.

Stadel, S., 2016, 'Mark of the Beast', in A.E. Walter, P.C. Craigie, J.D. Douglas, R. Guelich, R.K. Harrison \& T.E. McComiskey (eds.), The Lexham Bible Dictionary, Lexham Press, Bellingham, WA

Westcott, R., 2020, 'Covid on chips', BBC, viewed 31 December 2020, from https:// www.youtube.com/watch $? v=$ _ jatojk4kk.

Wright, T., 2011, Revelation for everyone, SPCK, London. 